\title{
CHRONIC CYTOTOXICITY OF MANCOZEB IN ALBINO RATS
}

\author{
Sleem, F, R. A; Abou Elmagd, M. i . and Llalfy, M. M. \\ Departmenl of Forensic Mediclne and Toxicology. \\ Faculty of Veterinary Medidne. Mansoura unlversity.
}

\begin{abstract}
The oral $L_{50}$ of manoozeb was determined The obtained results showed that. LD50 of mancoxois was $2143.6 \mathrm{mg} / \mathrm{kg}$. B. W'. For studying the chronic cylotoxtc of fects, eighty male albtno rals weighing $9010100 \mathrm{gm}$., were diulded into four groups (20 jor each). The Srst group used as control. Second, third and fourth given mancozeh orally through stomach tube at doses of 1/10.1/20. 1/40 of calculated oral LD50 respectively twice weekly. After 20 weeks the anunals were sacriflced, blood were collected anai sera uere separated for blochemical determinalion. Bone marrow was extracted from the fernurs and pispared for detectlon of chromosomal aberrattons. Liver, kldney. spleen, and brain were preserved in buffered formulth for hislopalhological changes. One gram of fresh livers were homogentzed in $10 \%$ dlstilled water for delermtnatton of DNA and RNA contents. All used doses of mancozeb caused doses dependent signifcant increase in $y$ glutamyl transfcrase actulty. Both doses of $1 / 10$ and I/ $20 \mathrm{LO}_{50}$ showed signilcant increase in serum allcallne phosphalase actulty. All doses showed signiflcant increase in senum aspartate aminomansferase activity. All doses showed dose dependert signifcant increase in serum urea level. All doses showis dose dependent slgniflcant decrease in serum glucose level. All doses showed dose dependent slgnificunt increase in serum cholesterol level Mancozeb showed no signifcant in serum butubin level. Chromosomal aberrations showed a dose dependent slgniflcant increase which appear in the form of frogments. gap. ting and slicked chromosomes. Doses of mancozeb $\left(1 / 10\right.$ and 1/20) LD $D_{50}$ showed signifcant increase li: quantily of RNA. There is no stgufficant changes observed in DNA of lluer conients of all treated groups and control. Hislopathologlcal changes revealed that. liver showed focal subcapsular coagulative necrosis infutrated with numerous leukacytes as mononuclear cells and glant cells. Hyperplasia of eplthellal lining of blle ductules besides newiy formed blle ductules surrounded with few mononuclear cells and fubroblasis in the portal area and the adjacent hepatocytes showed apoplosts. Congestlon of the portal blood vessels surrounded wh mononuclear cells and large vesicular nuclet and the
\end{abstract}


adjacent hepalocytes showed pressure atophy. Biain showert congestlon, hemuirahage and focal encephalomalcta. Kidney showed congestion of the coricical blood ucssels besides focal congultalue necrosis of some renal tubules. Spleen showed maderate depletion of lympiracytes from whitc pulp besides numerous siderocytes and congestion in red pulp.

The main conclusions of this sludy are mancozeb has chronic cylotoxts effects mantfesled by elther histopathological or blochemical changes in addition to delelentous effects on nuclets as chromosomal aberrations and apoptosis. all these changes may lead to rnutagenesis and probable carcinogenesls which should be considered and need extensive sturties since the mancozeb is whidy used effective funglcides elther in agriulture fleld or fresh food preservalives.

\section{GTTRODUCTYON}

The extenslve use of pesucides and the rlsks they pose to humaik health and the environment are now the focus of the world concem. All living crealure tested throughout the world arc polluted with pestlcldes such as birds, Ish, wild Mfe, domestic aninals. live stock and human belng Including newborn bables (Mozes, 1992 and Davis. 1993)

The use of pesticides over the past 50 years has been resulted In the pollution of the soll, water, plant. and animal species. This pollution has created a long lasung environmental problem especlally the members of the organcilonne class of pesticldes where they reslgtant $w$ environmental degradatlon and have been labeled as persistent accumulator (Rought et al., 1989).

Mansour (2004) showed that Pestlcldes have contributed lo great Increases in crop ylelds and in the quantly and vanety of the dlet. Also. they have helped to limit the spread of certaln diseases, but pesticides have harmitul effects, they can cause injury to human health as well as to the environment. The range of these adverse health efrecls Includes acute and persistent injury to the nervous system, lung damage. infury to the reproductive organs, and dysfunction of the immune and endocrine systems. birth defects. and cancer.

The use of pesiucldes has been increased dramatlcally in both developed and developing countrles durng the last few decades, whth doubling every 10 years, between 1946 and 1985 about 600000 tons of pesucldes annually were exported and used in developlng countries. about 50000 Lons of these were used for publlc health problems (Jan et al., 1987). Dichjocarbamates are wdely used as funglcldes because of thelr efflcacy against a broad spectrum of fung and their associated plant diseases. Dithiocarbamates are also used in Industry as slimtcides in water-cooling systems, in sugar. pulp, and paper manufacturing. and as vulcanization accelerators 
and antuoildanl, in rubber. sccause of thelr chelating projerties, they are also used as scavengers in waste-: ait.r tr.itment. (Pand et al 1995).

Mancozeb is u. it to proirct many frull, vegetable. nut and Reld crops against a wide spectrum of dlseases, including potato blight, lear spot. scab (on apples and pears) and rust (on ros. es). It is also used for seed treatment of cotton. potatoes. corn, safflower. sorghum, peanuts, tomatoes. flax and cereal gralns (Hayres and La: 5 1980). Mancozeb has been classifled as urllkely to present acute hazard in nonnal use by the WHO Recommended Classiflcation of Pesticldes by liazard. when bandled in accordance with instructions (WHO 1.892).

Mancozeb. Is one of the inost commonly used funglcldes in commerctal use for several decades. Nevertheless, up to now, no adequate published experlmental sludles on the carclnogenlr ity of Mancozeb have been publislied. Because of the importance of the compound and of the number of people potentially exposed (workers engaged in the production and use of the funglclde, people living in agrtcultural areas where the compound is sprayed. and people consumins polluted products (Belpoggt et al 2002).

There are a whde range vartation of oral LD50 of mancozeb which determined in rats In many researches which ranging from 5000 to $14000 \mathrm{mg} / \mathrm{kg}$. B.W. (Ivanova and Chemlshanka 1969 , Watts and Chan 1984 and Chapman 1986).

The aill of thls study was evaluate the chronlc cytooxlc elfects of mancozeb in addiuon to detect the LD50 due to a wide range varlation of oral LD50 of mancozeb in rat.

\section{MATERLALS AND METHODS}

Pertlclde: Dithane M 45 WP (Mnacozeb). was kJudly obtalned from EL-Nasser Company of Intermedlate Chemucals, Egypt

Common name: mancozeb

Trade name. Dlthane $\mathrm{R}-45$

Chemleal neme: Manganese ethylene bis (dichlocarbamate) complex wlth zinc salts

Cbemlcal formula: $\left(\mathrm{C}_{4} \mathrm{H}_{6} \mathrm{MnN}_{2} \mathrm{~S}_{4}\right) \times\left(\mathrm{C}_{4} \mathrm{H}_{6} \mathrm{~N}_{2} \mathrm{~S}_{4} \mathrm{Zn}\right)$

Molecular weight: 541.064

Experlmental andmals:

Male albino rats wefghted from 90 to $100 \mathrm{gm}$ obtained from expermental unlt. Faculty of vet- 
bilnary h.tedlclne. Zagazlg Unlversity. Animals were apparently clinical healchy and were housed In stalnleos steel cages with wood shavings as bedding. Animals were accommodaung to laboratory conduson for two weeks before being expertmented. Rats were mainialned on balanced ratlon of barley and dry mlik. Water and feed were glven ad liblium throughout the experimental perlod.

\section{Deterulnatlon of medtan lethal dose $\left(L D_{50}\right]$}

Twenty dive male alblno rats weightng 90 to 100 gn wire randoinly distributro into nue groups for delemination of median lethal dose $\left(\mathrm{LD}_{50}\right)$. The Groups given inancozeb al doses of 0. 1000. 2000. 4000. $8000 \mathrm{mg} . / \mathrm{Kg}$. B. W. respecuvely orally using stomach lubu. The experi. mental animals were observed for 24 hours. The clinlcal sims. mortallues. and gross leslons were recorded biough lic cxpermental pertod. The $\mathrm{LD}_{50}$ value was calculaced according to the method described by Fitl (1852) using the following formula:

$\log m=\log D+d(k-1) / 2+d f$

Where $m$ median effecuve dose ar exposure.

$0=$ the lonest dose lested.

$d=$ the logarlitili of the constant ratro between dosages levels.

I: constant value uulained from speclal lables. for the propu: $k$ the total number or level lested $-k+1)$

l'he conndence interval $95 \%$ was deternuned according to thr. same melhod using follown:; formula.

$\log m \pm 2.179 \delta \log m$

Where $\log m=\log L D_{50}$

$\delta \log m=d . \delta f$

$d:$ the logarlthm of the constant ratlo beturcen dosages levels

$f$ : a consiant value obtained from special lables (wob, 1952)

\section{Experimextal desigo}

Elghty male albino rats weighting $906100 \mathrm{gm}$. divided Irilo foul groups $(20)$ for each the nrst group used as control. Second. third and fourth given wancozcu orally through stor.iarh tube at doses of $1 / 10.1 / 20.1 / 40$ of calculated $L_{50}$ respectuvely curce weekly. All rats weight. 
ed wekly to matntain the dose constant all over the pertod of experiment after 20 weeks the animals wice sacrinced, blood were collected and serum were separated for blochemical determinatuon. Bone martow were extracted lrou the femurs and prepared for detecuon of chromosomal abenation. Liver, kldney. spleen, and brain were preserved in buffered formalin for histopathological changes. One gram of fresh livers were homogenized in $10 \%$ distilled water for deterninaLIon of DNA and FNA contents.

i:icheraical analyale:

The activity of serum ganuna-glutanyl transferase Gendler and Kaplan (1984), Serum alkaline phospatase (KInd and King, (1954), the activty of aspartate aminouransferasc (Reitman and Frankel (1957), serum g)ucose level Kaplan (1984), total s'rum bllirubin (Jendrasslk and Grof (1938). serum urea (Patton and Crouch (1977) and serum cholesterol were estlmated (Nalto and Baplan (I 984 ).

Chromosomal aberratlons detaction:

Chromosomal aberiatlons study was performed according to the method of Choudbury et al. (2004).

Determination of Deox:rtbonuclelc acid (DNA) :

Liver DNA contents were deteinined colourmelncally by the diphenylamine procedure descrlbed by Dhscie and Suhwarz (1937).

Determlnation oi rbonuclelc acld (RNA) :

Liver RNA contents were measured calorimetrically using arcinol procedure described by Mejbam (1939).

\section{Cllnleal signs and necropsy flndiags:}

Clinical slgns were observed in polsoned rats throughout the experimental pertod. Autopsles were performed in alh rats and Ussues were examlned. macroscoplcally and bistopathologically. For histopathological examination the ussues were nxed in $10 \%$ neutral buffered fol malin and were processed for routunc histopathologlcal examination (Carson and Frelda. 1990). 


\section{Statistical analysis:}

Data obtained in this study were subjected statisucally analyzed for variance (ANOVA). and least signifleant difference (LSD) as described by Snedecor and Cochran (1989).

\section{RESULTS}

Determination of $\mathrm{LD}_{50}$ of mancozeb :

\section{Biochemical findings :}

Regarding to the effect of mancozcb on $\gamma$ glutamyl transferase activtty, all used doses of mancozeb $1 / 10,1 / 20$ and $1 / 40 \mathrm{LD}_{50}$ caused doses dependent significant increase in $\gamma$ glutamyl transferase activity. Both doses of $1 / 10$ and $1 / 20 \mathrm{LD}_{50}$ showed significant Increase in serum alkaline phosphatase activity as compared to the control group. All doses of mnacozeb (1/10. 1/ 20 and $1 / 40 \mathrm{LD}_{50}$ showed doses dependent significant increase In serum aspartate aminotransferase activity as compared to the control group. All doses of mancozeb (1/10, 1/20 and 1/40 $\mathrm{LD}_{50}$ showed doses dependent significant tncrease in serum urea level as compared to the control group. All doses of mancozeb (1/10,1/20 and 1/40 LD 50 shored doses dependent sigisncant decrease in serum glucose level as compared to values of the control group. All dosis of mancozeb $\left(1 / 10,1 / 20\right.$ and $1 / 40 \mathrm{LD}_{50}$ showed dose dependent signlficant increase serum cholesterol level as compared to vaiues of the control group. All doses of mancozeb $11 / 10,1 / 20$ and $1 / 40 \mathrm{LD}_{50}$ silowed no significant changes in serum biltrubin level as compared to the control group. All this results are summarized in table 2.

\section{Chromosomal aberrations :}

Chromosomal abenations were a doses dependent and showed slgnificantly increase in all doses of mancozeb $\left(1 / 10,1 / 20.1 / 40 L D_{50}\right)$ which appear in the form of fragments. gap. rinn and sticked chromosomes. This results summarized in table 3 . and fig. IA, B, C and D.

\section{Effect of mancozeb on nucleic acld (DNA and RNA) :}

Doses of mancozeb $\left(1 / 10\right.$ and $1 / 20 \mathrm{LD}_{50}$ ) showed significant Increase in quantity of RNA as compared to the control group but there is no significant was observed between dose $1 / 40 \mathrm{LD}_{50}$ and control. There were no significant were observed in DNA of liver contents of all treated groups and control. The results are fllustrated in Table 4.

\section{Histopathological findings :}

Liver showed focal subcapsular coagulative necrosis infitrated with numerous leukocytcs as Mansoura, Vet. Med. $J$.

Vol. VIII. No. 2, 2006 
mononuclear cells and g,ant cells. Hyperplasla of eplthellad lining, of bilc ductules luestdes newly formed bllc ductulce surrounded with few inononuclear cclls and nbroblasts in the portal area and the adjaccnt liepatocytes showed apoptosis. Congestlon of the portal blood vessels surrounded with mononuclear cells and large venilcular nuclel and the adjacent hepatocytes showed pressure atrophy necrosis at dose of $1 / 10$ and $1 / 20 \mathrm{LD}_{50}$ of inancozeb Liver showed congeston of the hepatlc blood vesseis and liepatic sinusolós ivith inononuclear cell Inflitratlon at dose of $1 / 40 \mathrm{LD}_{50}$ of mancozeb. Thls result illustrated In $\mathrm{ng} .2 \mathrm{~A}, \mathrm{~B}$ and $\mathrm{C}$. Brain showed hemomahaglc congestion and rocal encephalomalcla at doses of $1 / 10$ and $1 / 20 \mathrm{LD}_{50}$ of mancozeb But group 3 intubated with ]/40 LD 50 of dnancozeb showing congestlon. Thls result lllustrated in fig. 2D. IJoney showed congestion of the corucal blood vesscls besides focal coagultalvc necrosis of some renal tubules al dose of $1 / 10$ and 1/20 LD 50 of mancozcl Kidney showed congestion of renal blood vessels at dose of $1 / 402 D_{50}$ of inancozeb. This rasult illustrated In $\mathrm{ng}$. 3A and 3 . Spleen showed moderate depletion of lymphocytes from whltc pulp besides numerous slderocytes and congestion In red pulp at doses of $1 / 10$ and $1 / 20 \mathrm{LD}_{50}$ or mancozeb. But group 3 intubaled

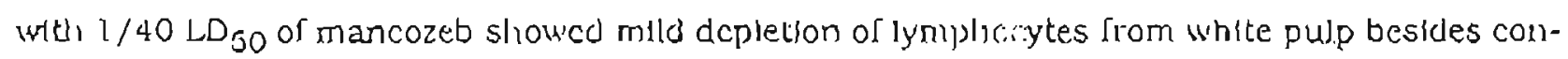
gestlon of the red pulp ithis result illustrated in $n g$. $3 C$ and $D$.

\section{DISCUSSION}

There is a widc ranice varalion of lhe oral $\mathrm{LD}_{50}$ of inancozeb in ials in many researcluts. for this reason we determined $L D_{50}$ belore starting the expermintal study. The present study Inve:ugated the oral median lethal dose (LDjol of mancozeb in male albino rats was $2143.6 \mathrm{kng} / \mathrm{kg}$. B. W. which disagree with Iranova and Chemistanka (1069) who reported that oral LD 50 In male rats was $14000 \mathrm{mg} / \mathrm{kg}$ B.w. and In female rats $12000 \mathrm{mg} / \mathrm{kg} \mathrm{b.w}$. And also dlsagreed with Watte and Chan (1984) who determined the inedlan lethal dose of mancozeb admunistered orally to male mouse, rat, and rabblt, the dose was recorded more than $5000 \mathrm{mg} / \mathrm{kg}$. B. W. Chapman (1896) reported that $L D_{50}$ or mancozel in rats was $5000 \mathrm{mg} / \mathrm{K} . \mathrm{g}$. B. W. The oral $\mathrm{LD}_{50}$ in rat was acceptable and attributed the difference due to dirferent stratns of rat..

Chromosomal abertations were dose dependent wU, $\left(1 / 10,1 / 20\right.$ and $1 / 40$ of $L_{50}$ ) and were In the form of fragments. gap. nng and sucked chromosomes. Signlifant Increase in the rrequencles of cells with stuctural chromosomal abertations and slster-chromatd exchanges In short-tern culture of penpheral lymphocyte of workers occupauonally exposed to mancozeb during lts production (Jablonlcka et al, 1889). Dithane caused genotoxic effect of bone marrow cells of male albino mice cautam and Kapoor 1991. The chromosomal abertallons observed were fragments, rings, dicentric chromosomes, ceminal chromalld delellons, chromatid gaps 
and breaks. In addition to these chromosornal aberrations. physlological cffects such as uneven stretching of chromath materal, end-to-end chromosomal assoclations, exchange configurations, clumplng, stlcklness and centromerlc assoclations were also observed (Grautam and Ra. poor 1991. Solonesizi et al 2002 studied the mutagenlclcy of both zlneb and azzurro in Chlnese hamsler ovary cells. Conccntratuons of $0.1-25.0 \mathrm{microg} / \mathrm{ml}$ o「 zineb or azzurto induced a signiflcant dose-dependent increase In sister chromaud exchange frequency over control values. The mutagenic effect of mancozso in two stralns of salmonella typhimurtum was recorded (Shukla et a 2004) and postulated that the true mulagensc potentjal of mancozeb may be masked by its toxdc enfect. Vasuder and Krishnamuthy (1804) Investugated the cytogenelcity of both DIthane $M-45$ and Baygon In mlce, nelther pesucide Induced a significant Increase In the number of chromosomal abcrations in gi'mn cells or in the percentage of erythrocytes micronuclel. In addition to these reports which indicaled the mutageniclty of mancozeb. other reports indlcated the dlrect damage effects of mancozeb on both DNA and RNA which constitule the baslc struclure of chromosomes. Nicolas (1982) found that when rats exposed to mancozeb with a dose of $100 \mathrm{ppm} /$ day, the clrcadian rhythms of RNA. DNA and proteins in the thyrold and aldrenal slightly affected but was stausiscally signillcanl and also the resucular RNA rhythm shows multuple peaks. Perocco et al. (1989) studled the toxic and DNA.dBmaging actuvlties of the funglcldes mancozeb and thiram on hiuman lymphocytes cultured in vitro with or without an S-9 mlx microsomal metabollzing system. Gupta aad Mehrotra (1892) studed the effect of mancozeb on mouse $9 k / n$ omlthine decarboxylase actulty and DNA synchesls. Omlthine decarboxylase actuvity was exhlbited a peak level at 5 hours but when cycloheximde was used, an inhtbltor of proteln synthesls, ornlthine decarboxylase induction was Inhlblted. The rate of DNA synthesls also Incrcased by mancozeb, as Indicated by thymidine |3Hi in coroporation into skun DNA. Induction of ornthine decarboxylase DNA symthesis was among the events probably involved in tumorigentc actlon of mancozeb In mouse $5 \mathrm{k}$.n .

YAO et al. (2004) found hJghly positive correlation between total GCT actuvity and the total RNA level of rats liver. The observed significant increase of quantlty of DNA and RNA due to mancozeb adminisiration atributed to genotoxictly of mancozeb. Calviello et al. (2006) studied DNA damage and apoptosis Induction by Mancozeb In nbroblasts cultured In viluo and in pertpheral blood mononucleated cells Isolated Irom Wistar rats.

The results obtained from the present study revealed that chromosomal aberrations when rate exposed to mancozeb for twenty weeks, also RNA contents in the Ilver was affected and apoptosis in the hepalocytes in addluon to alteration of llver functlon enzymes especlally gamma glytamyl transferse activlty. Kovalszky et al, (1996) and Lopez et al (1986) showed that the inductlon of gamma glytamyl transierse un altered hepatocyces may permit these cells to utilbe 
extracellular glutathione to preserve thefr internal plutathione levels. Glulathione s-transferase inductjor allows glutathione utilization for the protection oi the altered hepatocyte after exposure to xenoblotics, such as pronoting agents. Thus. Uhe comblned effects of gamma glytamyl transíersc and clutathlone S-transferase. in a toxlc environment. may provide for the enhanced prollferabon observed in pre reoplastic hepatocytes (Hendrich and Pitot 1987).

Also yao ct al. (2004) found that fela) llver-type gamma glytanyl (ransferse in sera and the liver of rats is closcly related to hepatotumorlgencsts. It can be used as a sensilive cnzymatic marker for the carly dagnusis of liver eancel: The observed incresu in famma glytamyl tran:

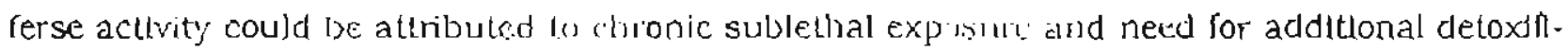
cation mecharsism as mancozsb Jccicased detoxlcating capacity of liver (Szepvolgyt et al. 1989). The oxldatlve cfiect of (ninconch suggest that its prooxtlant action may be Involved in the proapoptotic effect exerted by 1 tii; rompound in rat cells. It appears possible that the observed oxdative and genotoxlc damade may be Involved in the pathogenesis of varlous pathologles assoclated with the chronlc exposure to mancozeb. Including cancer (Calviello et al 2006).

Accordlng to the previous icports and prescut sudy, mancozeb has direct effects on the cells etther the cellular mombranc. cytoplasm and nucleus which detected in bistopathlogical changes as especlarly veslcular nuclel, DNA and RNA and caused chromosomal aberiations which lead to mulagenicily and apoptosis. All these changes could be considered the pre stcps for cancer formation. The absence of cancel formation in the present study mainly attributed to short period of exposure and snall doses usert in addition to low number of doses adminlstered (two doses wechly). The blochemical and histopathological changes of mancozeb were also cleed on the cells by Kackar et al (1999) who lound that mancozeb produced slgnincant chariges in the enzyme acuvllies of aspartate aminotransferase. alanlne aminotransferase. alkaline phosphataciu lactate dehydrogenase und acetylcholfnesterase throughout the period of study in a dose depcrident manner. The alterations ir the activlty of enzyiltes associated with pathomorphological changes suggest that the chronic exposure of mancozeb produced significant toxicologlcal effects in rats. The slight blochemlcat and hlstopathologlcal changes in the present study malnly attributed to the small doses used and the time belween the two successlve doses adminjstration which give chance of animal to tolerated and detoxiflcated of the most mancozel.

The rnaln conclusions of this study is that mancozeb has cytotoxlc eftects which manifested elther by histopathological or biochemical changes. In addition to deleterlous eflects on nucleus which lead to chromosomal aberration and apoptosis, all these changes may lead to mutagenesls and probable carclnogenic effects which requlre extenslve studies since the mancozeb is widely used as effective fungloides elther in agriculture feld or as fresh food preservatuer. 
Table I. Results of I Dso of mancozels in albino rat.

\begin{tabular}{|r|c|c|c|}
\hline Group & No. of rats /group & $\begin{array}{l}\text { Dose (mg/Kg. } \\
\text { B.W.) }\end{array}$ & No. of moradities \\
\hline 1 & 5 & 0 & 0 \\
\hline 2 & 5 & 1000 & 0 \\
\hline 3 & 5 & 2000 & 2 \\
\hline 4 & 5 & 4000 & 5 \\
\hline 5 & 5 & 8000 & 5 \\
\hline
\end{tabular}

Table 2. Serum biochenuical changes due to the effect of mancozeb on altino rat with different doses for 20 weeks (Mean $\pm S E$ ).

\begin{tabular}{|c|c|c|c|c|c|c|c|}
\hline 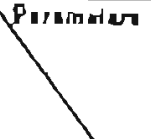 & 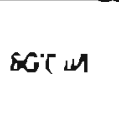 & $\begin{array}{l}A L P \\
\left\langle u^{\prime}(O 0 \mathrm{NJ})\right.\end{array}$ & AST (Wh) & $\begin{array}{l}\text { UREA } \\
\langle a y d||\end{array}$ & $\begin{array}{l}\text { gluease } \\
\text { (mydd ) }\end{array}$ & $\begin{array}{l}\text { sholajool } \\
\text { (mg/dn }\end{array}$ & $\begin{array}{r}\text { bilinubis } \\
\text { (mgas) }\end{array}$ \\
\hline Cootral & $\begin{array}{l}17.16^{2} \\
\pm 0.99\end{array}$ & $\begin{array}{l}89.46^{8} \\
\pm 1.09\end{array}$ & $\begin{array}{l}66.33^{4} \\
\pm 3.15\end{array}$ & $\begin{array}{l}37.76^{\circ} \\
\pm 1.01\end{array}$ & $\begin{array}{l}79.86^{4} \\
\pm 2.27\end{array}$ & $\begin{array}{l}73.46^{2} \\
\pm 4.79\end{array}$ & $\begin{array}{l}12.76^{\circ} \\
40.16\end{array}$ \\
\hline $1 / 10 \propto \alpha \perp D_{14}$ & $\begin{array}{l}45.33^{4} \\
\pm 2.46\end{array}$ & $\begin{array}{l}107.83^{4} \\
\pm 2.61\end{array}$ & $\begin{array}{l}116.5^{2} \\
\pm 4.75\end{array}$ & $\begin{array}{l}48.33^{5} \\
+2.28\end{array}$ & $\begin{array}{l}39.115^{5} \\
\pm 1.15\end{array}$ & $\begin{array}{l}103.85 \\
\pm 6.65\end{array}$ & $\begin{array}{l}11.66^{1} \\
\pm 0.38\end{array}$ \\
\hline $1 / 20$ or $L Q_{1}$ & $\begin{array}{l}412 \\
\pm 1.02\end{array}$ & $\begin{array}{l}102 \\
\pm 5.20\end{array}$ & $\begin{array}{l}108.16^{3} \\
\pm 4.69\end{array}$ & $\begin{array}{l}41.51^{25} \\
\pm 2.64\end{array}$ & $\begin{array}{l}30.38^{\circ} \\
\pm 0.54\end{array}$ & $\begin{array}{l}98.6^{20} \\
\pm 3.28\end{array}$ & $\begin{array}{l}13.35^{\circ} \\
=0.69\end{array}$ \\
\hline Uso of LD, & $\begin{array}{l}31^{8} \\
+1.56\end{array}$ & $\begin{array}{l}8666^{6} \\
\pm 4,83\end{array}$ & $\begin{array}{r}83.33^{2} \\
\times 3.20\end{array}$ & $\begin{array}{l}42.66^{4} \\
+1.50\end{array}$ & $\begin{array}{l}30^{8} \\
+1.62\end{array}$ & $\begin{array}{l}94.83^{35} \\
+3.13\end{array}$ & $\begin{array}{l}11.5^{6} \\
\pm 0.39\end{array}$ \\
\hline
\end{tabular}

Means in the same column having the same superscripls were nol significantly ditierenl $(p>0.05)$ 
Table 3. Chromosomal aberrations induced in bone marrow cells of albino rat given difficrent doses of mancozeb for 20 weeks

\begin{tabular}{|c|c|c|c|c|c|c|c|}
\hline \multirow[t]{2}{*}{ Groups } & \multirow{2}{*}{$\begin{array}{l}\text { Number of } \\
\text { examioed } \\
\text { cels }\end{array}$} & \multirow{2}{*}{$\begin{array}{l}\text { Nu. of } \\
\text { Aberruol } \\
\text { colls }\end{array}$} & \multicolumn{4}{|c|}{ Siructural A berrations } & \multirow{2}{*}{$\begin{array}{l}\text { Numerical } \\
\text { Aberratioss } \\
\text { (polj'ploldy) }\end{array}$} \\
\hline & & & Fragueal & $\overline{\text { Gap }}$ & Rlog & Silick & \\
\hline Conisol & 105 & 2 & 0 & 0 & 0 & 2 & 0 \\
\hline $1 / 10 L_{30}$ & 1100 & 19 & 9 & 3 & 3 & $\sigma$ & 0 \\
\hline $1 / 2 \cup L D_{-0}$ & 100 & 11 & 6 & 3 & 1 & 5 & 0 \\
\hline $1 / 40 L \bar{D}_{x y}$ & 100 & 8 & 4 & 1 & 0 & 3 & 0 \\
\hline
\end{tabular}

Table 4. EAects of ditierent doses of nancozeb on DNA and RNA contenis of ral liver ma/g. ivel lissues (nieans $\pm \mathrm{SE}$ )

\begin{tabular}{|c|l|l|l|l|}
\hline $\begin{array}{c}\text { Groups } \\
\text { Parameters }\end{array}$ & Control & $1 / 10 \mathrm{LD}_{50}$ & $1 / 20 \mathrm{LD}_{50}$ & $1 / 40 \mathrm{LD}_{50}$ \\
\hline DNA & $\begin{array}{l}15.875^{1} \\
\pm 0.32\end{array}$ & $\begin{array}{l}16.875^{1} \\
\pm 0.27\end{array}$ & $\begin{array}{l}16.125^{1} \\
\pm 0.48\end{array}$ & $\begin{array}{l}16^{1} \\
\pm 0.40\end{array}$ \\
\hline RNA & $\begin{array}{l}7.125^{6} \\
\pm 0.275\end{array}$ & $\begin{array}{l}8.50^{\prime} \\
\pm 0.15\end{array}$ & $\begin{array}{l}8.25^{1} \\
\pm 0.153\end{array}$ & $\begin{array}{l}7.25^{6} \\
\pm 0.46\end{array}$ \\
\hline
\end{tabular}

Neans in the same column having the same superseripts were noe significanly differenl $(y=0.05)$. 

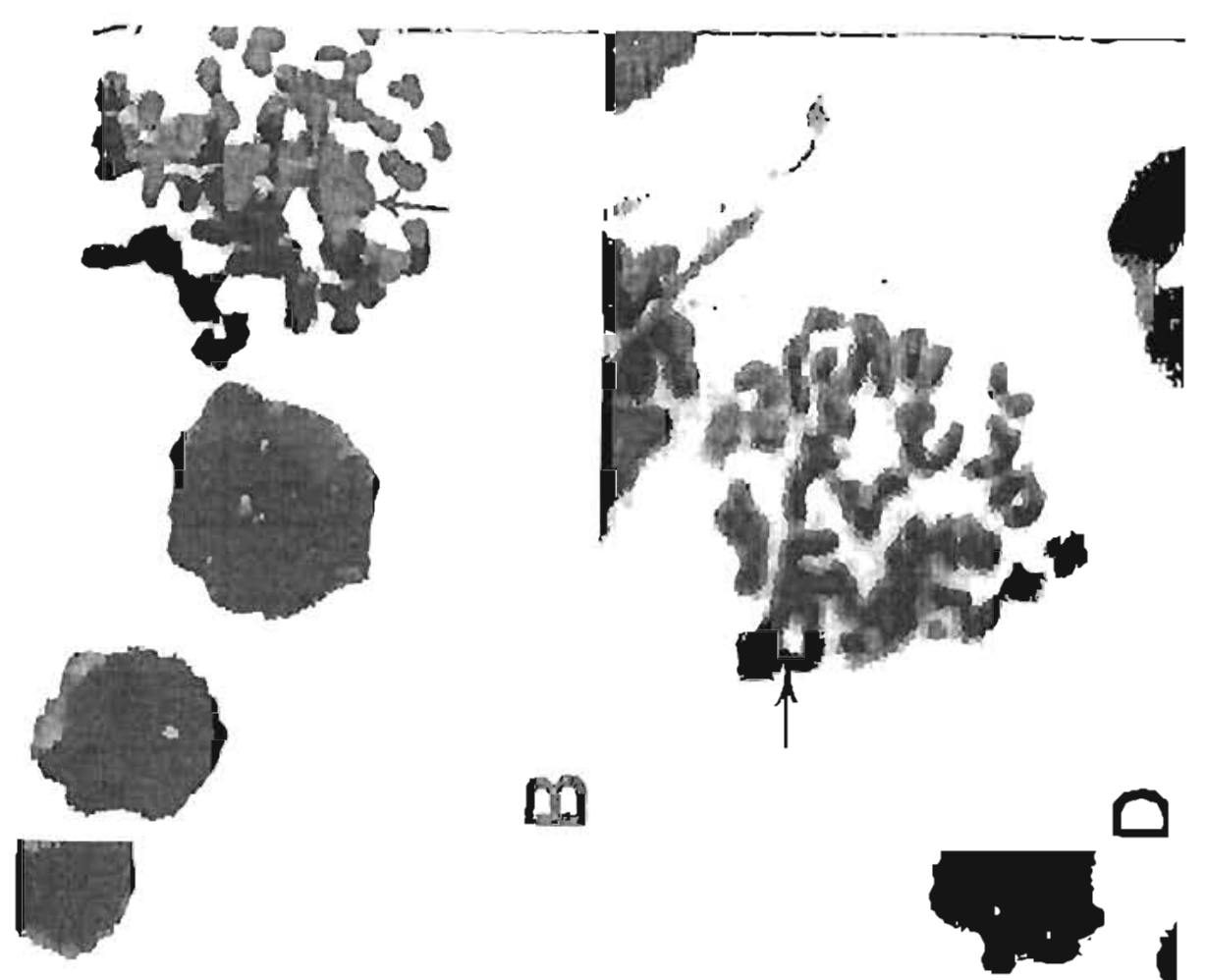

0
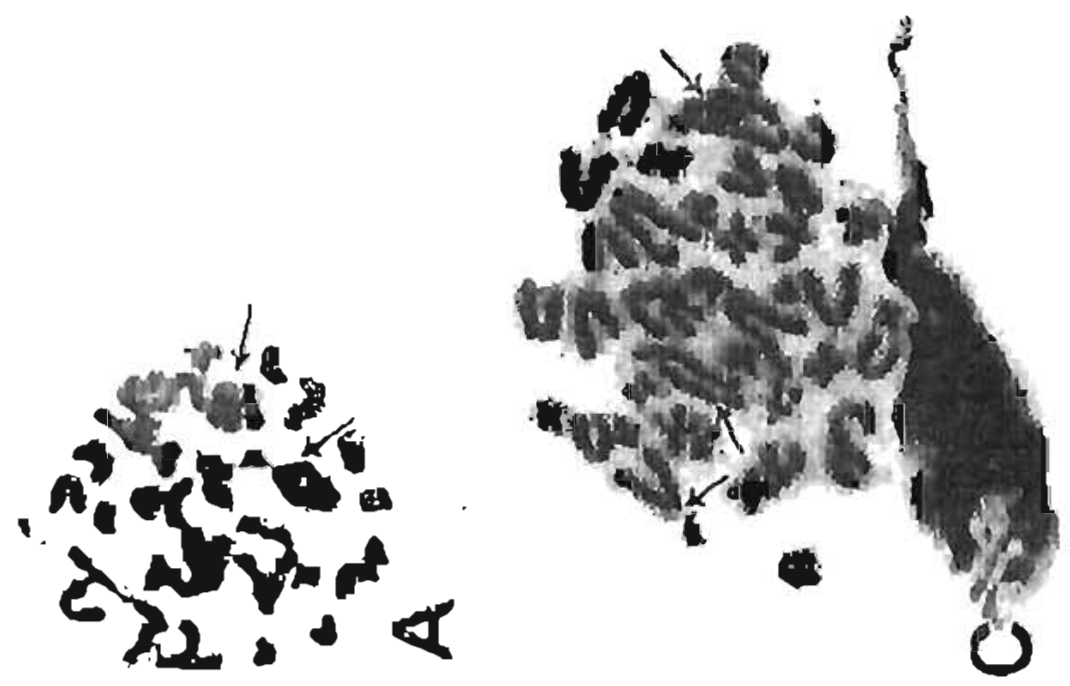

Pig. (1): Bone merto. cells of rass in melaphase spreading adminislered of mancozeb for 20 wecks with a showrng (A): Ring loosage of $1 / 10$ LD 5 d. (B): gap and sucked (dosage of $(/$ $10 \mathrm{LD}_{50}$ ). (C): (ragment (dosage of $1 / 10 \mathrm{LD}_{50}$ ). (D): Ring (dosage of $1 / 20 \mathrm{LD}_{50}$ ). 


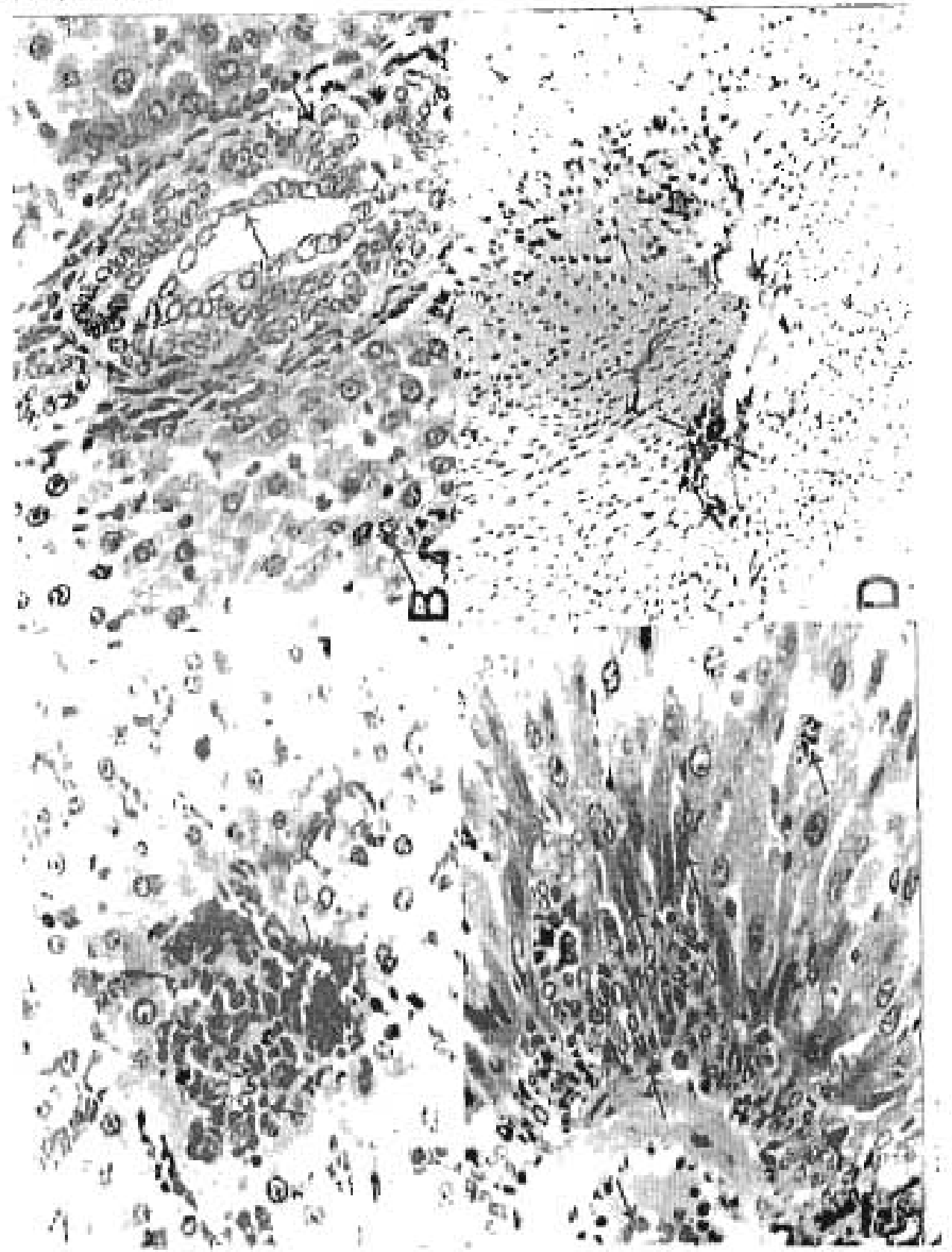

Fig, (2): (A): section of Liver from rat treali-d orally with $1 / 40 \mathrm{LD}_{50}$ of mancozeb showing congesUon of hepatic blood vessels and hepatic sinusolds with mononuclear cell infituduon $\left(\mathrm{H} \& \mathrm{E}, \mathrm{x} 520\right.$ ). (B): section of Liver from rat treated orally with $1 / 10 \quad \mathrm{CD}_{50}$ of mancozeb showtng hyperplasia of the eplthellal lining of blle ductules besides newly formed blle ductules surrounded with few mononuclear celis and flbroblasts in the portal area. The adjacent hepatocytes showed apoptosis [H\&E. $\times 520$ ). (C): Section of Liver from rat treated orally with $1 / 10$ LD $_{g 0}$ of mancozeb showing congestion of the portal blood vessels surrounded with mononuclear cells and large vesicular nuclel. The adjacent hepatocytes showed pressure atrophy necrosls (H\&E. x 520). (D): Section of brain from rat treated orally with $1 / 10 \mathrm{LD}_{\mathrm{so}}$ of niancozeb showing hemorrhage bestdes focal encephalomallcla (H\&E. $\times 130)$ 


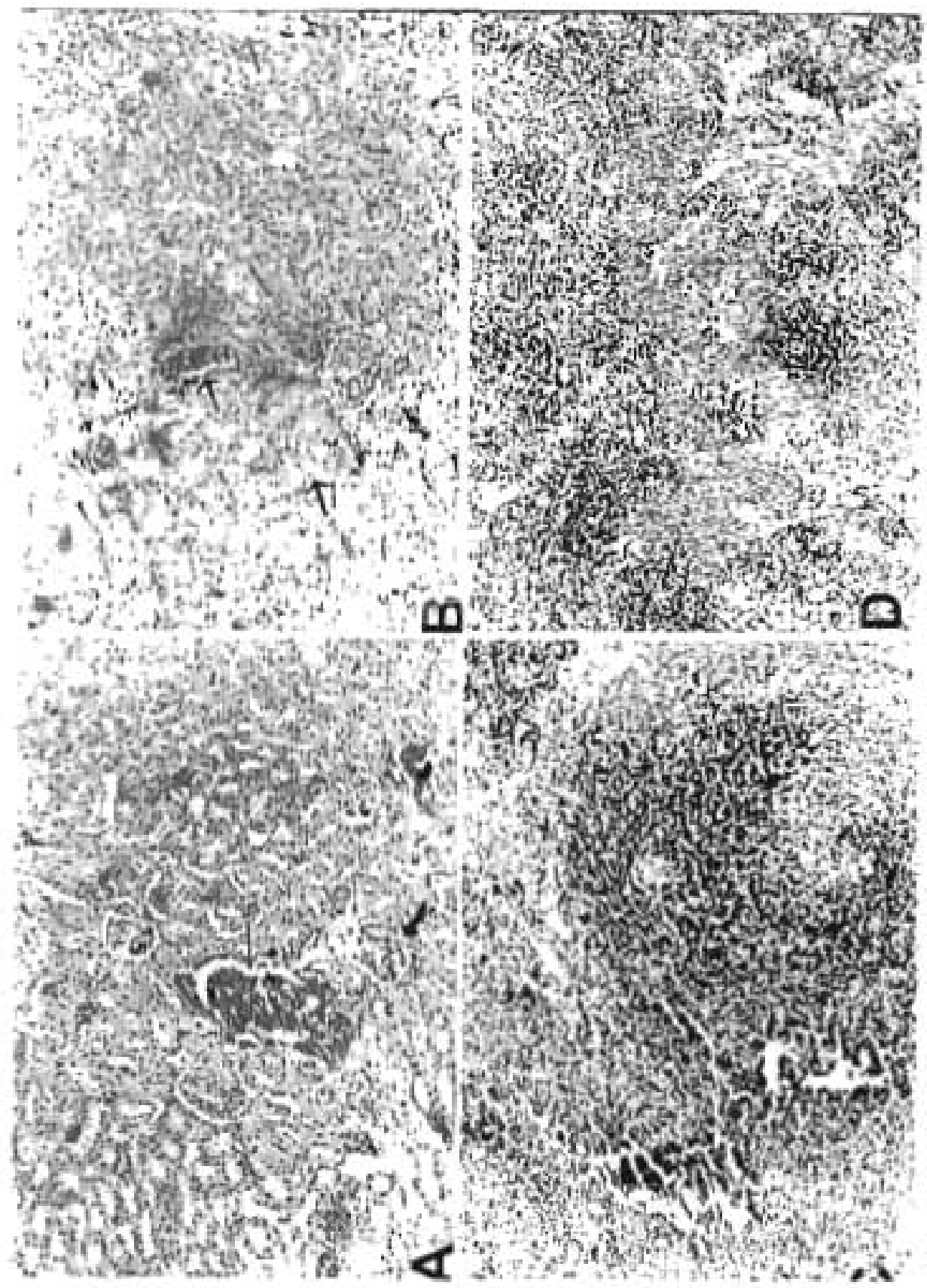

Fig. (3): (A): Section of kidney from rat treated orally with $1 / 40 \mathrm{LD}_{50}$ of mancoreb showing congestlon of renal blood vessels, encephalomalicta (H\&E. $x, 130$ ). (B); Section of kddney from rat treated orally with $1 / 10 \mathrm{LD}$ So of mancozeb showng congesuon of the cortl. cal blood vessels besides degenerated renal tubules . (HAE $\times 130$ ). (C): Sccton of spleen from rat treated orally with $1 / 40 L_{50}$ of mancozeb showing mild depletion of lymphocytes from white pulp besides congestion of the red pulp. $(\mathrm{H} \& \mathrm{E} \times 130)$. (D): $\mathrm{Sec}$. tion of spleen from rat treated orally whth $1 / 10 \mathrm{LD} \mathrm{D}_{\mathrm{SO}}$ of mancoseb showing moderate de: pletion of lymphocyirs from white pulp besides numerous siderocytes in the red pulp. (H\&E $\times 130)$. 


\section{REFERENCES}

Belpoggi fi., Soffrittl M., Guarlao M., Lambertinl L.. Cevolani D. and Maltont C (2002) : Resull:- of long-term experimental sudie. on the carcinogenicity of ethylerie bis. Uluriocarlaainae (mancozcl)) in ráls. Ann N Y Acad Scl. 982:123-130.

Calviello G.. Plcclonl E.. Bonlnsegua A. Tedesco B.. Magglapo N., Serlal 8., Woll P.I. and Palozza P. (2006): DNA Jamage ano apoptosis Inducton by the pesucide Mancozeb in ral cells: involvemone of the oildauve iuechanlsm Toxicol Appl Pliannacol. 2006211 (2):87-96.

Carson H. T. and Frelda L. (1990): Palnological kr.hnique in Histotechnology book. Arntilcan soclely clinical palhuloglst. pp. 4.30.

Chapmaa. M. J. (1998): Spcel/he polson. in Clinical Velerinang Toxicology. pp 94-95. Blackwell sclence Lid.

Choudoury R.C., Palo, A K. and Sath P. (2004): C.logente ilsk ausessmenl or eloposide from mouse bone marrow. J Appl To:ucol, $24(2): 115 \cdot 22$.

Dische and Subwarz (1973): Microcitem, ACl. 3:13. quoted from Abdel Salara X.M. (1983): Ph. thesis. Raculty of sclence. Ain Shanis unlecrsily.

Daws, C. C. (1993): Eimtrmental concerns about peslicldes use in Plifippine agrlcultuic. Scl. Lotal envtron. Suppl. Pall 1,203-306.

Cautam O.C. and kapoor L. (1991): Cenoto::ic effecls of ditlane M-4. on the bone martow cells of mice in vlvo. Experlenula, 4/(3):280-282.

Geadler and Baplan (1984): a colortinetrtc mechad for deterininaton of gamma glutamyl Lans. Cerase. Cun Chem the C.V. Mosby CO. Se Louss. Toronto. Pinceton 1120.1123.

Gupta K.P. and Mehrotra N. K. (19日2): SLAtus of orrlehine decarboxylase acuvity and DNA synthesis in mancozeb-exposed mouse gkin. Carcinogenesls. 13(1):131-13),

Hayes, W.J. and Lavo E.R. (1800) : Handbook of Pesuclde Toxucology, Vol. 3. Clossers of PesU. cides. Academic Press, lnc.. NY.

Heoditch S. and pleat H. C. (1987): Enzymcs of glulalhlone mietabollsm as blochemical mark. ers during hepatocarcinogenesis carcinogenesls 8(9):1245-3250.

Ioanova and Cbemisbanka. L. (1969): Toxjcologle characlerisucs of mancoecb in Bulgarani. Higienal Zdraveopazvare 12: 418.426.

Jabloulcka A. Polakora H. Karelora J. and Vargova M. (X8B9): Analysls of chromosome aberrallons and slster-chromatd exchangeg In pcripheral blood lymphocytes of workers 
whth occupauonal exposule to the mancozel-containing funglclde Novozlr Mn80 Mulal Res. 224(2): 1 43-6.

Ja D., Sbella H. Z., Awelka H. and HaOB O. A (1997): Pestlcldeg and cancer. Cancer Causes and Control. 8:420-443.

Jendmaskf. L. add Grof, P. (1838): A colormetric method for determ!naton or Serum bilirubin. Blochem. 3287,61 .

Kackar R. Envastava M. I. aud Rolzada R.B. (1999): Asscssinent of coxlcological effects of mancozeb in male rats anter chronic exposure. Ind(an J Exp 8lol. 37(6): 553.559.

Baplan L. A (1984): A colonmetric method for deterrunation of glucose. Clin Chem the C.V. Mosby CO. Si Louls. Toronio. Princetun 1032.1036.

Ulad P. R. N. aod klag. E.G. (2084): Estumation of plasma phosphalase by deceminallon of lindrolysed phenol with amino-anelpyrin. J. Clin. Padiol. 7:322.

Kovalazky 1. I.. Scbaif. Z.. Lapls X. and Jcaeg A (1908): Masker Enzymes of rat chemical hepatocarclnogenesls in hungan llver Tumors. Palhol Oncol Res. 2(1.2):56-58.

Lopex J. B., Balagegaram M., Thambyrajab V. and Thoor J. (1898): The value of liver func. Uon tests In hepatocellula carcinoma. Malays J Pathol, 19(2):95.99.

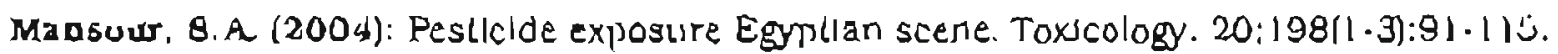

Mejban $w$. (1939): Uberide besummung Kelmer pentosemenge insbersonder in dertuatender adenyls aurez. Physiol.Chem. 228:117.

Moses. M. (1992): Peablides. In Puplic Heallih and Preventive Medicine .John. M. L. And Robert, B.W. Eds.Prenuc-Hall. Inter nauonal Inc. Press London, 479.489.

Nafto. H. K. and Kaplan. A (1984): A colorimetric melhod for determination of Cholesterol. Clln Chem the C.V. Mosby CO. SL Louls. Toronto. Princeton 1194-11206 and 497.

Nicolau, G.Y. (1982): Circadlan rhythms of RNA. DNA and proteln content in the ral thyrold. adrenal and lesug in chronlc pestlcide expogure. I. Efrects of a lungicke (Mancozeb). Endocrinologu. 20(4):249.57.

Patton. C. J. and Crouch, S. R. (1977): A colonmetric method for delerminallon of serum urea Aral. Chem. 49:464-469.

Paul H., Gabrtel B. and Jerome R. H. (1996): Ethylerieblsdlchiocarbamates and Ethylenelhiou. rea: Possible Humar Health Hazards. Environmenlal Heallh Perspecives 103: (6) 568. 573.

Perocco P. Gmatuoes M. A. Campad AO. sod Pord G. C. (1989): ToxlC and DNA-damaging Mansoura, Vet. Med. J. Vol. Vat, No. 2, 2006 
activities of the fungicldes mancozcb and hilram (TMTD) on human lyinphocyics in vitro. Teratog Carcinog Mutagen. $9(2): 75-81$.

Reitman S. and Frankel 8. A mer (1957): A colorimetric method for delermination of serum glutamle oxalace Uc and glutamlc pyiuvic transaminase J. Cinn. Pathol. 28:56.

Rought S. E., Yau F. M., Chugg L. F., Dol R. H. and Chaung R.Y. (1999): Effect of chlorinated hydrocarbons. bepatochlor, chlordane, and toxaphene on retinoblastoma lumor suppressor In human lymphocyles .Toxlcol .Lell. 104: (1-2) 127-135.

Stubla Y.., Taneja P., Arora A and Sinba N. (2004): Mulapenle potential or Mancozeb In Salmonella lyphimurlum J Enviton Palliol Toxicol Oncol. 2004:23(4):297-302.

Sacdecor G. W. and Cochran w. G. (1999): StaUsLlcal Melirods, Elghun Eultion. bowa Slate University Press.

Solonerbl S., Gonzalez M., irreio E., Rekgosa M. A and Larracaendy M. L. (2002): Enecl of dithocarbamate pesticide zincb and Its conimerclal formulation azzumo. IJl. Genotoxic evaluation on Chinese hamster ovary (CHO) cclls. Mutat Res. 2002 514(1-2):201-212.

Szeprolgyl J., Nagy K., Sajgone V. K., Regoly Merel A, Soor K., Totb H., Pinter A. and Antal M. (1989): Subacute coxicological examlnaton of Dithane M-45. Fd. Chem. Toxdc. 27(8): $531-538$.

Vasuder, $V$, and Krishnamurthy, N. B. (1084): in vivo cylogenelic analyses of the carbamate pestldides Dithane M-45 and Baygon in mice. Mutation-Research,-Mulation-ResearchLetlers. 323: 3. 133-135.

Watts M. H. and Chan F. K, (1884): Dithane M-45 (1984): acute oral coxiclty study In rats and mice. Unpublished report No. 83R-213a $+\mathrm{b}$ Trom Rohm and Haas Company, Spring House, Pennsylvanla, USA Submilted to WHO by Rohm and Haas Company. Spring House, Pennsylvania, USA.

Well, C. (1952): Tables for convenient calculation of medlan-effecuve dose (LD50 or ED50) and Insuruction in Uicir use. Blometrics 8:219-263.

WHO (1992): The WHO recommended classincation of pesilicldes by hazard and guidellnes to classincation 199?-1993 [WHO/PCS/92.14]. Avallable from the Intemauonat Programme on Chemlcal Safely, World Healuh OrgantzaLun. Geneva. Swlzerland.

Yao D.F., Dong Z.Z., Yoo D.i., Wu i. H., Wu W., gIU L.W.,Wang H.M. and Meng X.Y. (2004); Abnormal expression of hepatoma-derlved gamma-glutaniyltransferase subtyping and its early alteraton for carcinogenesls of hepatocytes. Hepatoblliary Pancreat Dis int. 3 (4):564-70. 


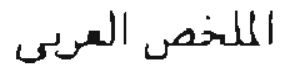

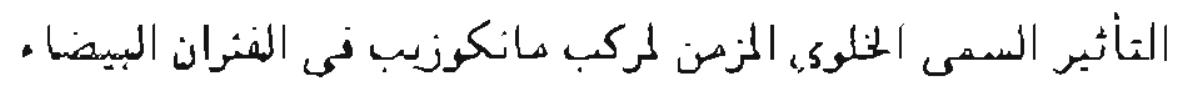

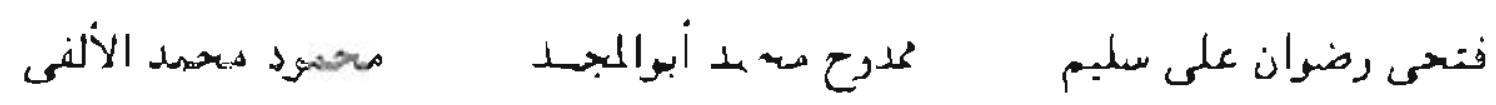

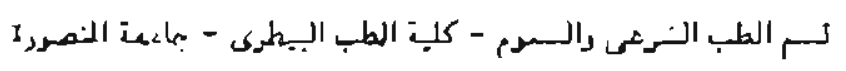

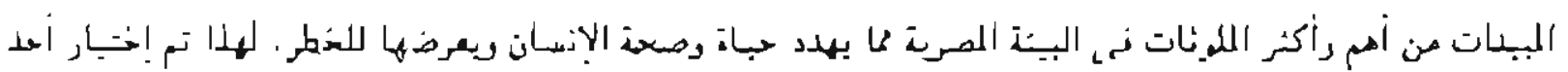

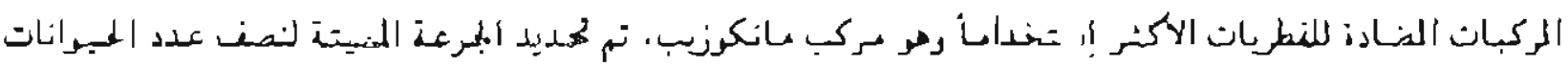

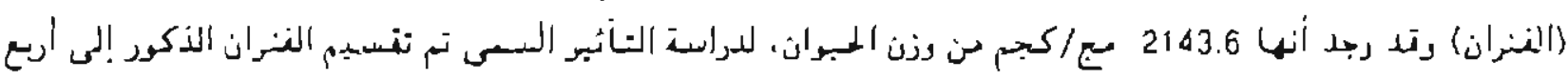

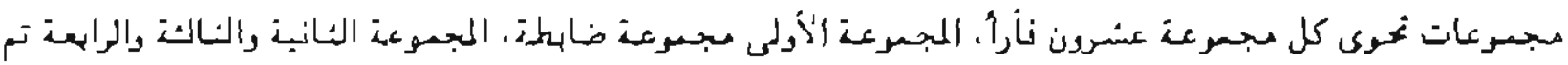

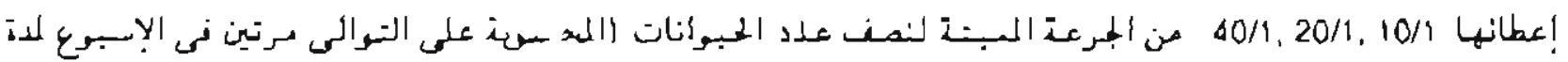

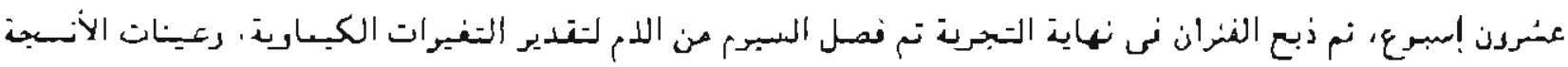

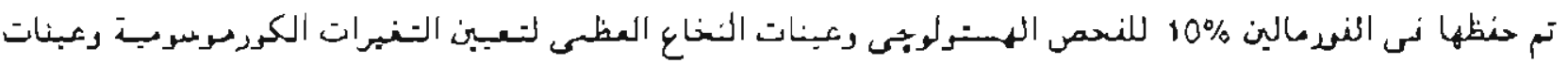

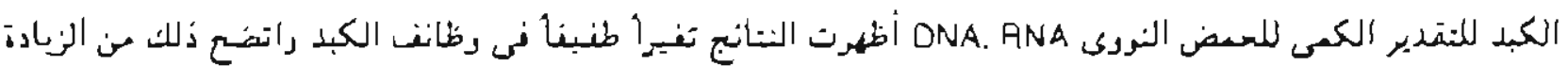

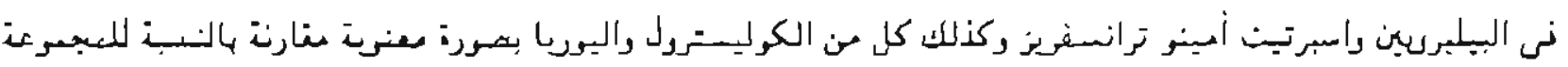

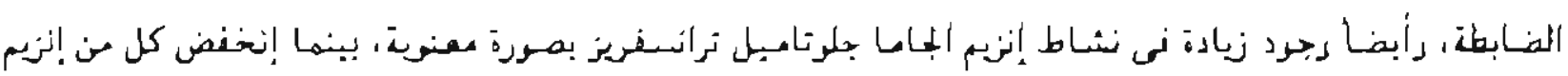

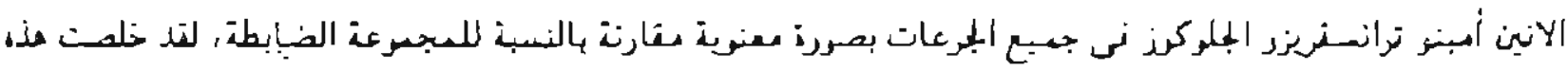

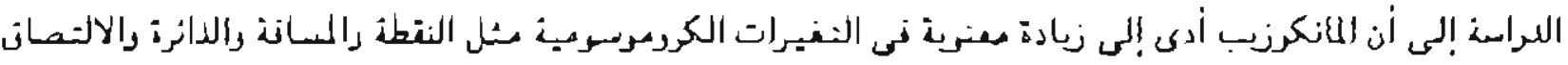

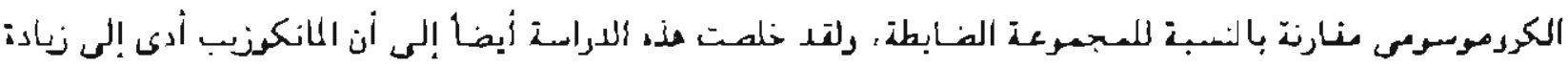

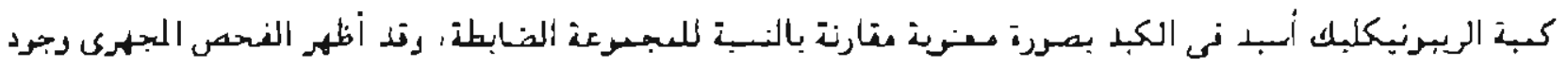

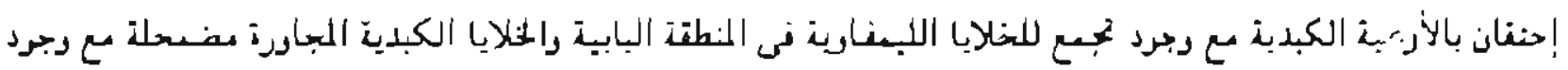

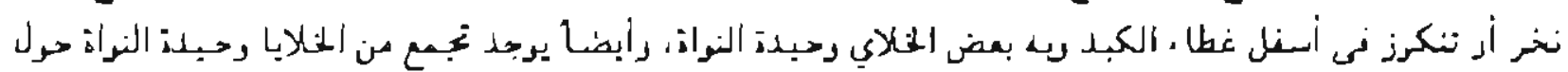

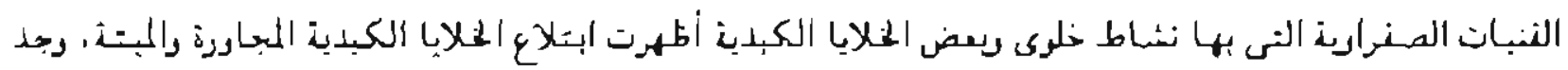

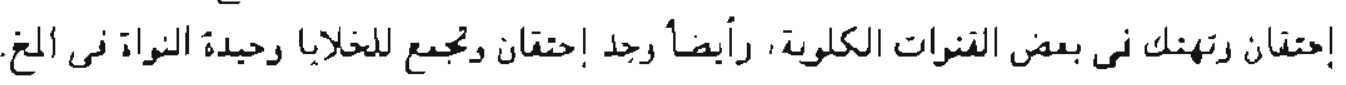

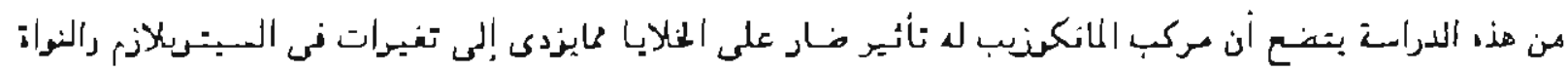

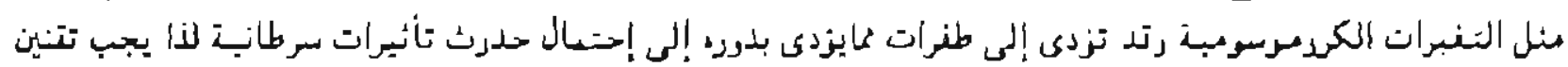

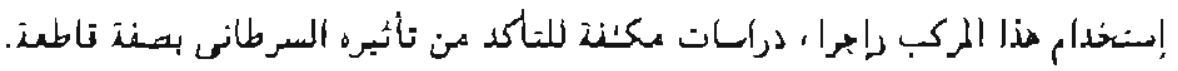

